\title{
The Larval Stages of Benizuwai-gani, Chionoecetes japonicus RATHBUN Reared in the Laboratory
}

\author{
Hiroshi MотоH*
}

(Received January 16, 1976)

\begin{abstract}
This study deals with the larval stages of Benizuwai-gani, Chionoecetes japonicus, and with the comparison of those between $C$. japonicus and Zuwai-gani, $C$. opilio. There are two zoeae and one megalopa. The larval stages of $C$. japonicus are morphologically similar to those of $C$. opilio excepting some characters as follows: 1) Chromatophores of zoeae and megalopa are vermillion or crimson in C. japonicus and brown or reddish in C. opilio. 2) C. japonicus is generally bigger than $C$. opilio in zoeae and megalopa. 3) Length of postero-lateral spine on 3rd abdominal segment is more than 1.3 times the length of the 4th abdominal segment in $C$. japonicus, but is shorter than (rarely equal to) that in $C$. opilio. 4) Ischiopodite of cheliped has no spine in $C$. japonicus, but it has spine in $C$. opilio, in megalopa.
\end{abstract}

Two species of edible crabs of the genus Chionoecetes occur in the Japan Sea. The Zuwai-gani, Chionoecetes opilio (O. FABRICIUs) is caught by the Danish seine from depths of 200 to 350 meters and is the most important commercial species in some districts along the Japan Sea coast. But recently production is acutely decreasing due to probable overfishing.

The Benizuwai-gani, Chionoecetes japonicus RathBUN is captured by the basket trap from a much deeper bottom of 700 to 1,500 meters. The catching efforts for them are increasing compensating those for $C$. opilio. In recent years, annual production in the Hokuriku and San-in districts reaches about 22,300 tons of the shell crabs with a value of 2,430 million yen (8.1 US million dollars, approximately) to the fishermen (personal communication from Katsuchiyo ITo).

The descriptions of crab larvae belonging to the genus Chionoecetes have been published by AIKAWA ${ }^{1-3)}$ (prezoea), KON $^{4}$ (prezoea), ITO $^{51}$ (prezoea), KURATA ${ }^{6-7)}$ (first and second zoeae and megalopa), KUWATANI, et al. ${ }^{8 !}$ (prezoea and first zoea), HaYNes ${ }^{9}$ (prezoea and first zoea) and MoтоH $^{10)}$ (first and second zoeae and megalopa). All the descriptions were based on the specimens obtained from eggs of $C$. opilio except KuRATA's second zoea and megalopa which were obtained from the plankton; HAYNEs ${ }^{91}$ (prezoea and first zoea of $C$. bairdi from eggs); MoToH ${ }^{11)}$ (brief observation of prezoea and first zoea of $C$. japonicus from eggs). FUKATAKI ${ }^{12)}$ and ITo and IKEHARA ${ }^{13 !}$ surveyed the occurrence and distribution of the planktonic larvae of Chionoecetes in the Japan Sea.

* Aquaculture Dept., SEAFDEC (Southeast Asian Fisheries Development Center), P.O. Box 256, Iloilo, Philippines（本尾＼cjkstart洋：東南アジフ漁業開発センター羡殖部局） 
But actually, they could not distinguish between $C$. opilio and $C$. japonicus owing to their close resemblance except pigmentation.

As far as the present author is aware, the complete larval development of $C$. japonicus has not yet been studied. The objective of this report is to give a detailed description and to summarize differences and similarities between $C$. japonicus and $C$. opilio, providing a basis and method for future identification of zoea and megalopa of all the species belonging to the genus Chionoecetes.

\section{Materials and Methods}

On February 2, 1973, eight ovigerous females, caught by the basket trap at a depth of about 930 meters in Toyama Bay, Japan Sea, were placed in the wooden tank at the Fisheries Experimental Station of Toyama Prefecture. Three days later, these crabs were transported to our laboratory and placed in a plastic tank of 1,000 liter capacity. The rearing methods were almost the same as those adopted by Мотон $^{10)}$.

Hatching occurred on February 7 to 9, 1973. Temperature of the sea water ranged from 4.5 to $11.2^{\circ} \mathrm{C}$, and specific gravity varied from 1.022 to $1.025(\rho 15)$ from February to April. Heavy mortality was observed during the second zoea and megalopa. More than ten larvae were observed for each stage under microscope.

\section{Description of Larvae}

All the larvae hatched as prezoea and they molted into the first zoea in about two hours. There are two zoea and one megalopa stages in the larval development.

First zoea (Fig. 1): The carapace has four spines, a dorsal spine and a rostral spine approximately equal in length and a pair of lateral spines. The eyes are not stalked. The length from the tip of rostral to tip of dorsal spine is 4.85 to $5.52 \mathrm{~mm}, 5.21 \mathrm{~mm}$ in average. The width of carapace including both lateral spines is 3.46 to $3.98 \mathrm{~mm}, 3.69 \mathrm{~mm}$ in average. The distance between outer margins of eyes is 0.85 to $1.20 \mathrm{~mm}, 1.02 \mathrm{~mm}$ in average. The abdomen consists of five segments and the telson. The telson is bifurcate. Each furca of the telson bears three setae on the inner side and a small spine each on the lateral and dorsal edge respectively. The postero-lateral margins of $3 \mathrm{rd}$ and 4 th segments are prolonged into a pair of spines extending beyond the posterior margins of the following segments. The 2nd and 3rd segments bear a pair of lateral hooks. The antennule is conical and uniramous with three terminal processes, two broad flat aesthetes and a smaller seta. The antenna is almost as long as the rostral spine, and its peduncle tapers to a point with several rows of setules. The exopodite ends in three setae. The lengths of these setae are in the ratios: $1: 1.5$ to $2.3: 2.4$ to $4.2,1: 1.8: 3.1$ in average. The mandible is small with an irregular cutting edge, without palps. The endopodite of the 
maxillule bears six setae of equal length that are arranged in three pairs and one more seta is present at the base of endopodite which is an apparently separate segment. The basipodite and coxopodite have seven setules respectively. The scaphognathite of the maxilla has 12 or 13 long soft plumose hairs including two or three thick ones, and the trilobate endopodite bears six setae. The basipodite and coxopodite are bilobed and have the spinal arrangement of 5 or 6-5(4) on basipodite and 4-4 on coxopodite. The end-

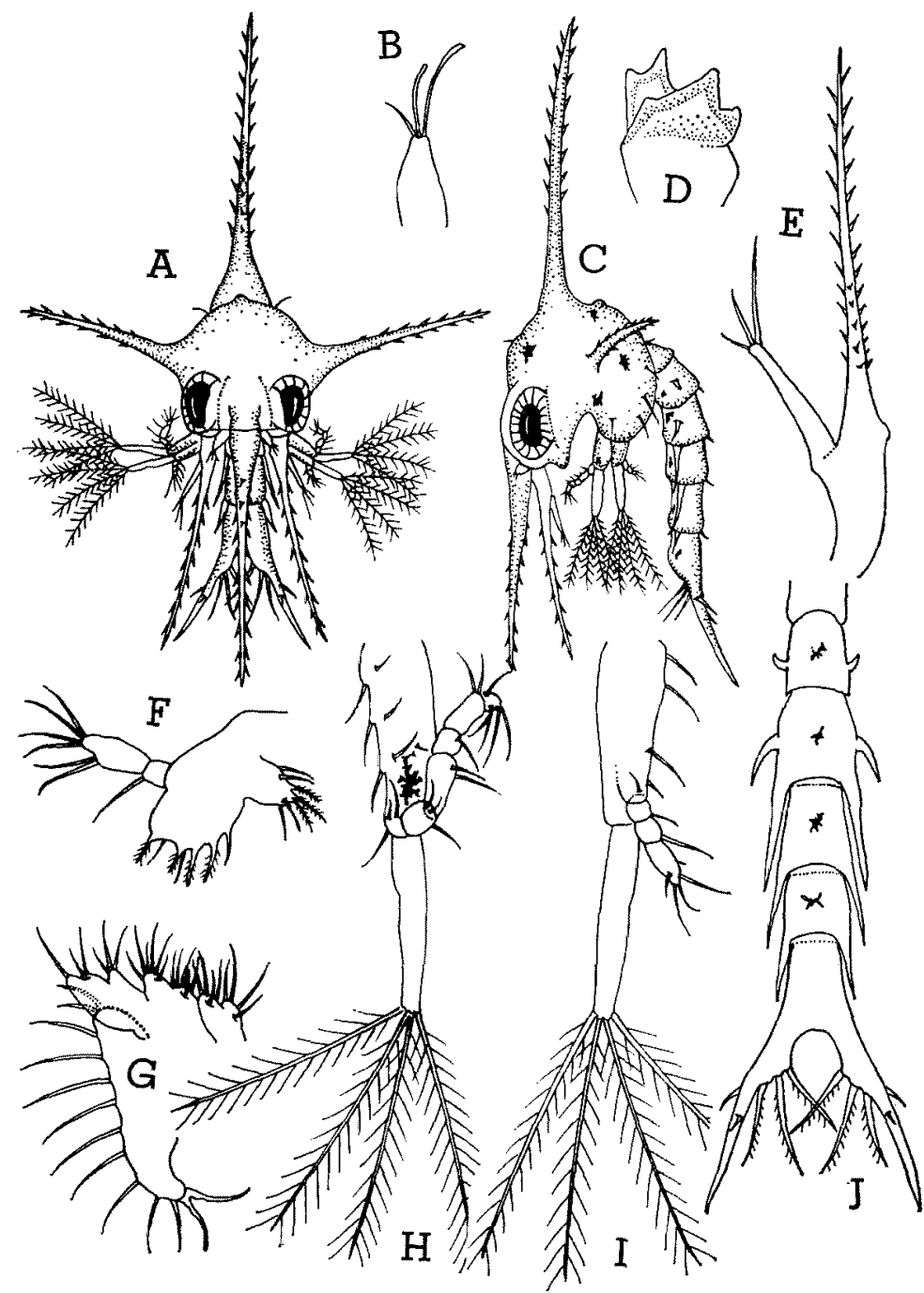

Fig. 1. Chionoecetes japonicus RAthbun. First zoea. A, dorsal view; B, antennule; $\mathrm{C}$, lateral view; $D$, mandible; $E$, antenna; $F$, maxillule; $G$, maxilla; $H$, first maxilliped; $I$, second maxilliped; $\mathrm{J}$, abdomen in ventral view. A, C, $\times 20 ; \mathrm{B}, \mathrm{D}, \mathrm{F}, \mathrm{G}, \times 150 ; \mathrm{E}, \mathrm{H}, \mathrm{I}, \times 75$; $\mathbf{J}, \times 40$. 
opodite of the first maxilliped has five segments with a spinal arrangement of 3-2-1-2-5 from proximal to distal segments. Four natatory hairs are present on the distal end of the exopodite. The second maxilliped also has four natatory hairs and spinal arrangement of $1-1-5$ on the three segments of the endopodite. One of five spines on the terminal segment is very minute.

Second zoea (Fig. 2): The length of the larva from the tip of rostral to tip of dorsal spine is 5.72 to $6.91 \mathrm{~mm}, 6.56 \mathrm{~mm}$ in average and the width of carapace including both lateral spines is 3.33 to $3.92 \mathrm{~mm}, 3.69 \mathrm{~mm}$ in average. The second zoea has stalked eyes and the distance between outer margins of eyes is 1.57 to $1.87 \mathrm{~mm}, 1.74 \mathrm{~mm}$ in average. Aesthetes on the antennules are increased to nine or ten and are divided into two groups: one in the proximal group and the other in the terminal group which consist of six or seven large and two small sensory flagella. The antenna has a developing endopodite. The mandible has an unsegmented palp. The coxopodite and basipodite of the maxillule have six to eight and eight to nine spines respectively.

The endopodite of the maxillule consists of two segments with a spinal arrangement of 1-6 (rarely 2-6). An additional plumose hair is located on the protopodite of maxillule near the base of endopodite. The trilobate endopodite of the maxilla bears six setae. The bilobate basipodite bears five and the bilobate coxopodite of the maxilla bears four setae on each lobe respectively. The scaphognathite of the maxilla has 23 to 27 (mainly 26 or 27) long soft plumose hairs including two or three thick ones. Each maxilliped bears six natatory hairs on the exopodite. The inner margin of each furca of the telson bears one additional spine without setule.

Megalopa (Figs. 3, 4): The megalopa is 2.89 to $3.37 \mathrm{~mm}, 3.16 \mathrm{~mm}$ in average in carapace length including rostral central process and 2.11 to $2.45 \mathrm{~mm}, 2.20 \mathrm{~mm}$ in average, in carapace width. Seven heavy processes are present on the carapace; three rostral processes, of which central one is longer than the lateral two, a pair of anterior gastric lateral processes, and a pair of cardiac dorso-lateral ones. Spines also project ventrally from the ischiopodites of the walking legs except for the chiliped and the fourth walking leg. The fourth walking leg has no conspicuous hair projecting from the tip of the dactylopodite. The inflated peduncle of the antennule is followed by two segments. The antenna consists of eight segments. The arrangement of the setae from the base to the terminal segment is 1-2-3-0-3-4-0-4 with a slight variation in number. The well-developed mandibular palp bears about eleven spines. The endopodite of the maxillule has no spine. The scaphognathite of the maxilla is very broad with about 70 soft plumose hairs. Setae on the coxopodite have increased to eleven on one lobe and six on the other. The basipodite has six spines on one lobe and eight on the other. The endopodite has only three or four setae on its basal portion. The first maxilliped has a well-developed epipodite with 


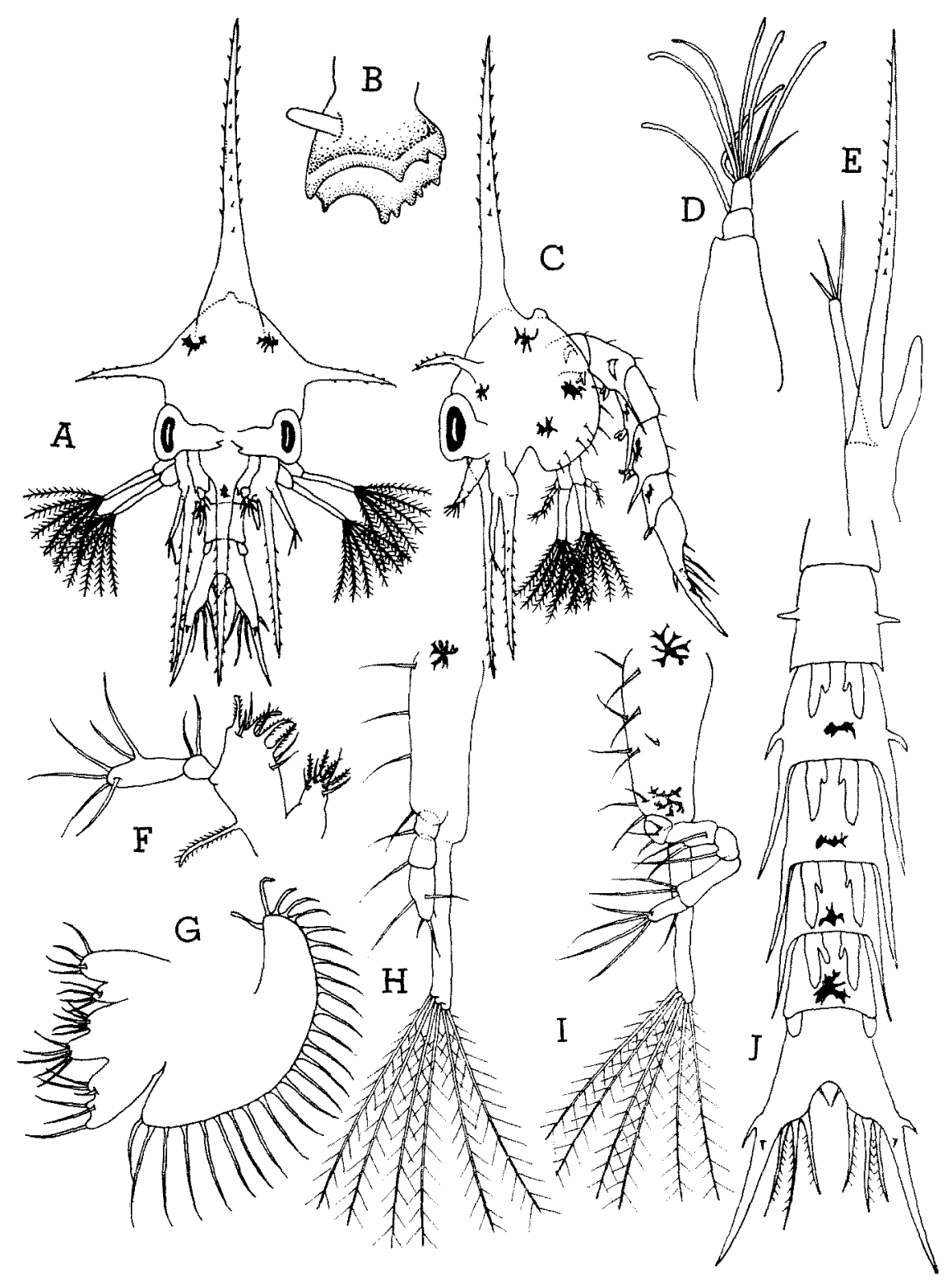

Fig. 2. Chionoecetes japonicus Rathrun. Second zoea. A, dorsal view; B, mandible; C, lateral view; $D$, antennule; $E$, antenna; $F$, maxillule, $G$, maxilla; $H$, second maxilliped, I, first maxilliped; J, abdomen in ventral view. A, C, $\times 20 ; \mathrm{B}, \mathrm{D}, \mathrm{F} \times 150 ; \mathrm{E}, \mathrm{H}, \mathrm{I}, \times 75$; $\mathrm{J}, \times 40$.

about 17 soft hairs. The broad endopodite has three spines at the distal end and numerous spines on the basipodite. One plumose and three or four terminal hairs are present on 


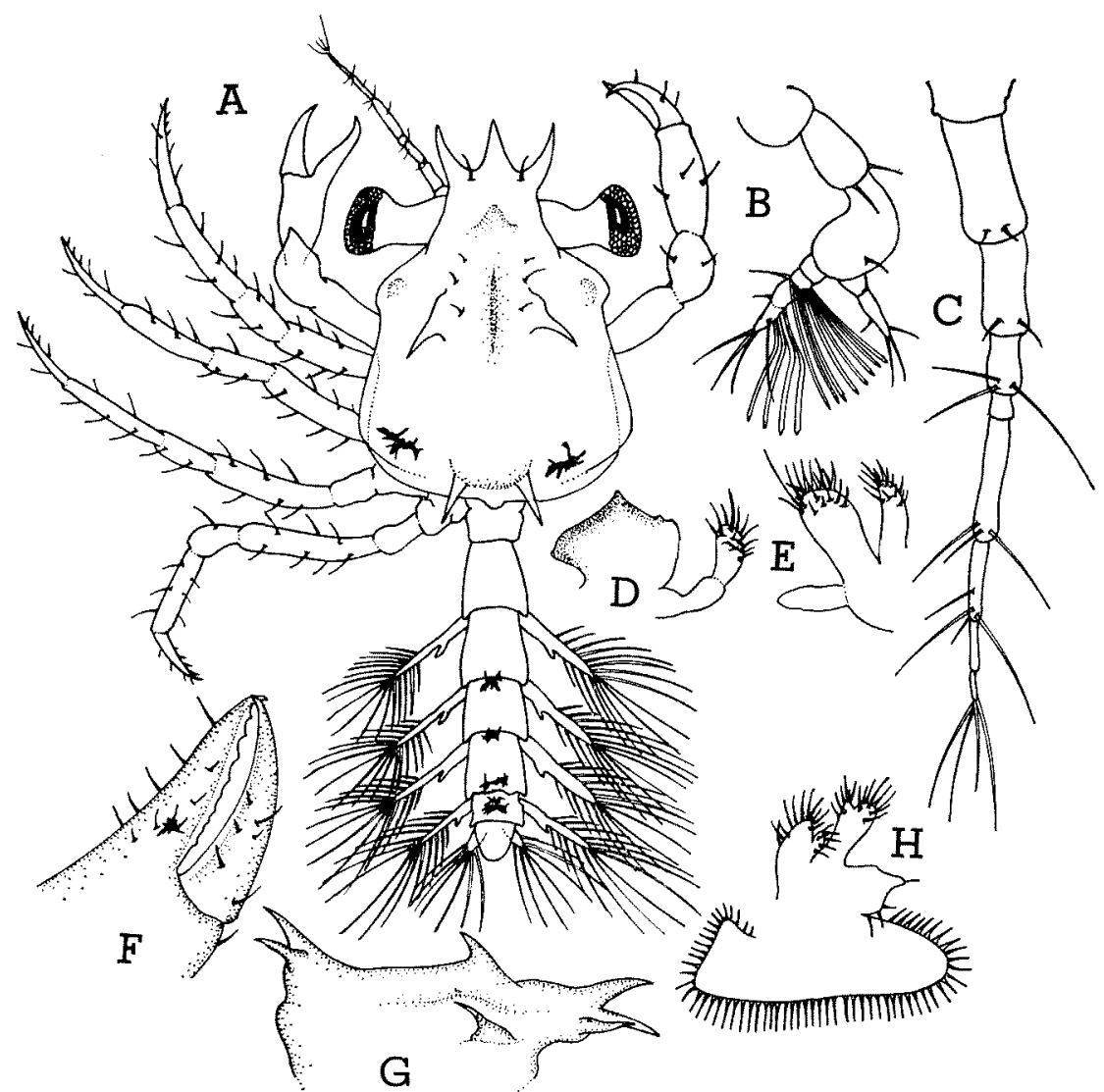

Fig. 3. Chionoecetes japonicus RATHBUN. Megalopa. A, dorsal view; B, antennule; C, antenna; $D$, mandible; $E$, maxillule; $F$, distal portion of chiliped; $G$, lateral view of carapace; $\mathrm{H}$, maxilla. A, G, $\times 30 ; \mathrm{B}, \mathrm{D}, \mathrm{H}, \times 75 ; \mathrm{E}, \mathrm{F}, \times 150$.

the exopodite. The endopodite of the second maxilliped consists of four segments with a spinal arrangement, from proximal to distal, of $0-2-5-7$. Four natatory hairs are now present on the terminal end of the exopodite. The well-developed epipodite is also present, with approximately 35 soft simple hairs. The third maxilliped has developed tremendously at metamorphosis from the second zoea to the megalopa. The endopodite has become quite massive and consists of four segments with numerous spines. The epipodite is well-developed with about 20 soft non-plumose hairs. The abdomen consists of six segments and the telson. Pleopods are present on 2nd to 5th segments and bear about 16 long plumose hairs for locomotion, with a variation in the number of hairs ranging 14 to 17 . There are seven (rarely six) plumose hairs on the uropod each side.

Differences in larval characters between $C$. japonicus and $C$. opilio The larval stages of $C$. japonicus are morphologically similar to those of $C$. opilio described by 


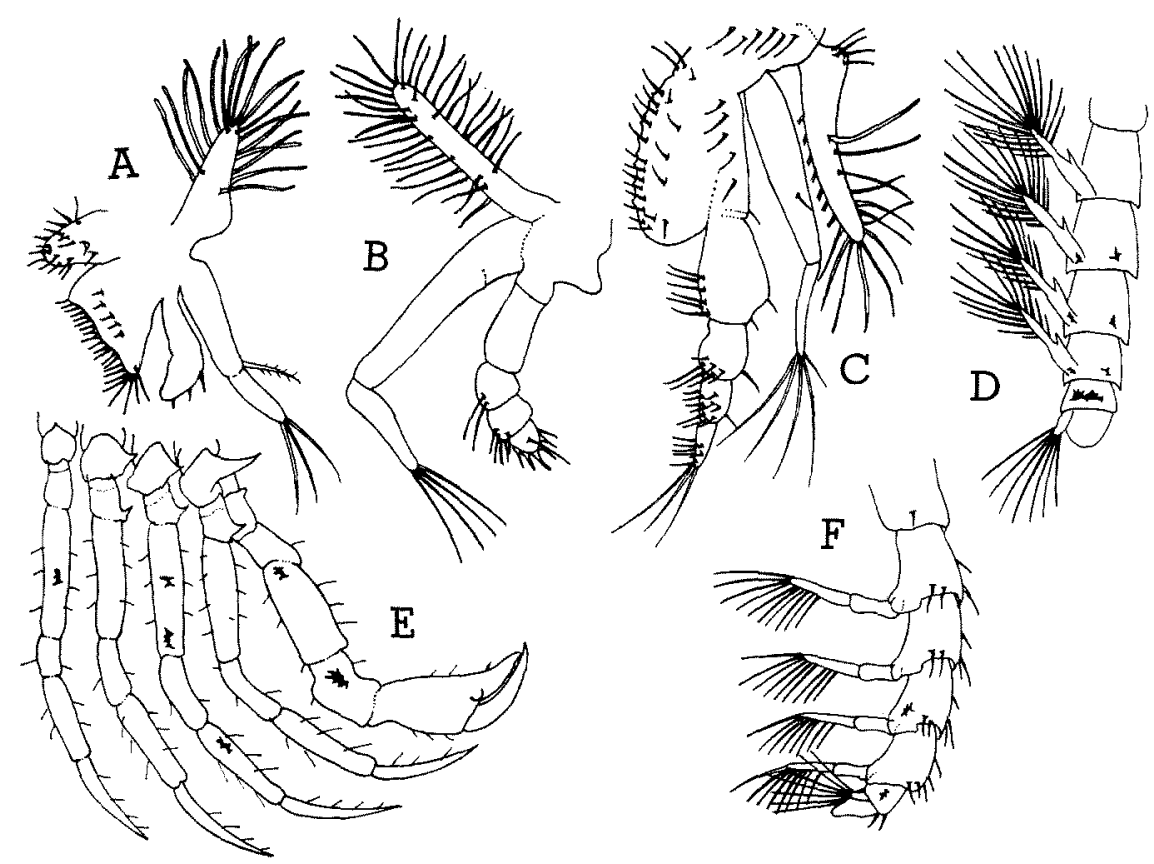

Fig. 4. Chionoecetes japonicus RATHBUN. Megalopa. A, first maxilliped; B, second maxilliped; $C$, third maxilliped; $D$, abdomen in ventral view; $E$, periopods 1 st to 5 th; $F$, abdomen in lateral view. A, B, C, $\times 75 ; \mathrm{D}, \mathrm{E}, \mathrm{F}, \times 30$.

KuRATA $^{61}$, KUWATANi et al.$^{8)}$, HAYNes' ${ }^{9)}$ and MotoH $^{10)}$. Variation in the number of setae on the appendages of the two species is responsible for a substantial portion of the differences between them. In case of the first zoea, the differences between two species are as follows:

1) the chromatophores are brown or reddish brown in C. opilio and vermillion or crimson in C. japonicus,

2) the length of posterior lateral spine on 3rd abdominal segment is more than 1.3 times the length of 4 th abdominal segment in $C$. japonicus, but is shorter than (rarely equal to) that in $C$. opilio.

In the second zoea, another differences, in addition to the two characters mentioned above, become apparent in the distance between outer margins of eyes and in the number of setae on scaphognathite as shown in Table 2. Finally, in the megalopa, C. japonicus is slightly larger in size than $C$. opilio as shown by present author and $\mathrm{MoTOH}^{10)}$. Further, differences between both species in the megalopa are as follows:

1) chromatophores are brown or reddish brown in C. opilio and vermillion or crimson in $C$. japonicus as in the zoeal stages, 2) the ischiopodite of the cheliped has a spine in C. opilio but does not have in $C$. japonicus. 
Table 1. Comparison of the characters of the first zoea of Chionoecetes opilio (O. FABRICIUs), C. bairdi RATHBUN and C. japonicus RATHBUN

\begin{tabular}{|c|c|c|c|c|c|}
\hline Characters & $\begin{array}{c}\text { KURATA } \\
(1968 \text { \& 69) } \\
(\text { Ch.o. })\end{array}$ & $\begin{array}{l}\text { KUWATANI } \\
\text { et al.(1971) } \\
\text { (Ch.o.) }\end{array}$ & $\begin{array}{c}\text { HAYNES } \\
(1973)(C h . o . \\
\& \text { Ch.b. })\end{array}$ & $\begin{array}{l}\text { Мотон } \\
(1973) \\
(C h . o .)\end{array}$ & $\begin{array}{l}\text { Moтон } \\
\text { (Ch.j.) }\end{array}$ \\
\hline \multicolumn{6}{|l|}{ Length of larvae from } \\
\hline $\begin{array}{l}\text { tip of rostral to tip } \\
\text { of dorsal spine in } \mathrm{mm}\end{array}$ & 4.5 to 4.9 & * & $\begin{array}{l}3.96 \text { to } 4.55 \\
\text { (average, } 4.17 \text { ) }\end{array}$ & $\begin{array}{l}4.8 \text { to } 5.4 \\
\text { (average, } 5.22 \text { ) }\end{array}$ & $\begin{array}{l}4.85 \text { to } 5.52 \\
\text { (average, } 5.21 \text { ) }\end{array}$ \\
\hline $\begin{array}{l}\text { Width of larvae includ- } \\
\text { ing both lateral spines } \\
\text { in } \mathrm{mm}\end{array}$ & $*$ & $*$ & $\begin{array}{l}2.52 \text { to } 2.97 \\
\text { (average, } 2.73 \text { ) }\end{array}$ & $\begin{array}{l}3.3 \text { to } 3.6 \\
\text { (average, } 3.34 \text { ) }\end{array}$ & $\begin{array}{l}3.46 \text { to } 3.98 \\
\text { (average, } 3.69 \text { ) }\end{array}$ \\
\hline $\begin{array}{l}\text { Distance between outer } \\
\text { margines of eyes } \\
\text { in } \mathrm{mm}\end{array}$ & * & $*$ & $*$ & $\begin{array}{l}0.9 \text { to } 1.0 \\
\text { (average, } 0.93 \text { ) }\end{array}$ & $\begin{array}{l}0.85 \text { to } 1.20 \\
\text { (average, } 1.02 \text { ) }\end{array}$ \\
\hline $\begin{array}{l}\text { Proportional length of } \\
\text { three setae on } \\
\text { antenna }\end{array}$ & $1: ?: 2$ & $*$ & $*$ & $\begin{array}{l}1: 1.7 \text { to } 2.3: 2.7 \\
\quad \text { to } 3.8 \\
\text { (ave., } 1: 1.8: 3.1 \text { ) }\end{array}$ & $\begin{array}{l}1: 1.5 \text { to } 2.3: 2.4 \\
\text { to } 4.2 \\
\text { (ave., } 1: 1.8: 3.1 \text { ) }\end{array}$ \\
\hline $\begin{array}{l}\text { Terminal process of } \\
\text { antennule }\end{array}$ & * & 5 & 5 & 3 & 3 \\
\hline $\begin{array}{l}\text { Spines outer margin } \\
\text { of telson furca }\end{array}$ & 3 & 2 & 3 & 2 & 2 \\
\hline $\begin{array}{l}\text { Lateral knobs on ab- } \\
\text { dominal segments }\end{array}$ & 2nd and $3 \mathrm{rd}$ & 2nd and 3 rd & 2nd and 3 rd & 2nd and $3 \mathrm{rd}$ & 2nd and $3 \mathrm{rd}$ \\
\hline $\begin{array}{l}\text { Spines on endopodite } \\
\text { of maxillule }\end{array}$ & $1-6$ & $1-6$ & $1-6$ & $1-6$ & $1-6$ \\
\hline $\begin{array}{l}\text { Spines on basipodite } \\
\text { of maxillule }\end{array}$ & $*$ & 7 & 7 & 7 & 7 \\
\hline $\begin{array}{l}\text { Spines on coxopodite } \\
\text { of maxillule }\end{array}$ & * & 7 & 7 & 7 & 7 \\
\hline $\begin{array}{l}\text { Spines on endopodite } \\
\text { of maxilla }\end{array}$ & $3-3-1$ & $3-2-1$ & $3-3$ & $3-3$ & $3-3$ \\
\hline $\begin{array}{l}\text { Spines on basipodite } \\
\text { of maxilla }\end{array}$ & $*$ & $5-5$ & $5-5$ & 5 or $4-5$ or 4 & 5 or $6-5$ or 4 \\
\hline $\begin{array}{l}\text { Spines on coxopodite } \\
\text { of maxilla }\end{array}$ & $*$ & $4-4$ & $4-4$ & $4-4$ & $4-4$ \\
\hline Setae on scaphognathite & 16 & 13 & 11 (rarely 12) & 12 or 13 & 12 or 13 \\
\hline Spinal arrangement & & & & & \\
\hline $\begin{array}{l}\text { on endopodite of } \\
1 \text { st maxilliped }\end{array}$ & $*$ & $3-2-1-2-5$ & $3-2-1-2-5$ & $3-2-1-2-5$ & $3-2-1-2-5$ \\
\hline $\begin{array}{l}\text { Spinal arrangement } \\
\text { on protopodite of } \\
\text { 1st maxilliped }\end{array}$ & $*$ & $3-3-3-3$ & $2-2-3-3$ & $2-2-3-3$ & $2-2-3-3$ \\
\hline Spinal arrangement & & & & & \\
\hline $\begin{array}{l}\text { on endopodite of } \\
\text { 2nd maxilliped }\end{array}$ & $1-1-5$ & $1-1-4$ & $1-1-5$ & $1-1-5$ & $1-1-5$ \\
\hline $\begin{array}{l}\text { Spinal arrangement } \\
\text { on protopodite of } \\
\text { 2nd maxilliped }\end{array}$ & $*$ & $1-1-1-1$ & $1-1-1-1$ & $1-1-1-1$ & $1-1-1-1$ \\
\hline
\end{tabular}


Table 2. Comparison of the characters of the second zoea of Chionoecetes opilio (O. FABRIcrus) and C. japonicus RATHBUN

\begin{tabular}{|c|c|c|c|}
\hline Characters & $\begin{array}{c}\text { KURATA } \\
(1969, \text { Ch.a. })\end{array}$ & $\begin{array}{c}\text { Мотон } \\
(1973, \text { Ch.o. })\end{array}$ & $\begin{array}{l}\text { Мотон } \\
(C h . j .)\end{array}$ \\
\hline $\begin{array}{l}\text { Length of larvae from tip of rostral to tip } \\
\text { of dorsal spine in mm }\end{array}$ & 6.0 to 6.9 & $\begin{array}{l}6.2 \text { to } 7.1 \\
\text { (average, } 6.2 \text { ) }\end{array}$ & $\begin{array}{l}5.72 \text { to } 6.91 \\
\text { (average, } 6.53 \text { ) }\end{array}$ \\
\hline Width of larvae including both lateral spines in $\mathrm{mm}$ & $*$ & 3.6 to 3.9 & $\begin{array}{l}3.33 \text { to } 3.92 \\
\text { (average, } 3.69 \text { ) }\end{array}$ \\
\hline Distance between outer margins of eyes in $\mathrm{mm}$ & * & $\begin{array}{l}1.3 \text { to } 1.5 \\
\text { (average, } 1.4 \text { ) }\end{array}$ & $\begin{array}{l}1.57 \text { to } 1.87 \\
\text { (average, } 1.74 \text { ) }\end{array}$ \\
\hline Proportional length of three setae on antenna & $1: ?: 2$ & $1: 1.90: 2.87$ & $1: 1.82: 3.00$ \\
\hline Terminal Processes of antennule & $*$ & 9 & 7 to 9 \\
\hline Spines outer margin of telson furca & 3 & 2 & 2 \\
\hline Lateral knobs on abdominal segments & 2nd and $3 r d$ & 2nd and 3 rd & 2nd and 3 rd \\
\hline Spines on endopodite of maxillule & $1-6$ & $1-6$ & $1-6$ \\
\hline Spines on basipodite of maxillule & $*$ & 7 or 8 & 8 or 9 \\
\hline Spines on coxopodite of maxillule & $*$ & 6 or 8 & 7 or 8 \\
\hline Spines on endopodite of maxilla & * & $3-3$ & $3-3$ \\
\hline Spines on basipodite of maxilla & $*$ & $6-6$ & $6-6$ \\
\hline Spines on coxopodite of maxilla & * & $4-4$ & $4-4$ \\
\hline Setae on scaphognathite & $*$ & $\begin{array}{l}20-23 \\
\text { (mainly } 22 \text { or: } 23 \text { ) }\end{array}$ & $\begin{array}{l}23-27 \\
\text { (mainly } 26 \text { or } 27 \text { ) }\end{array}$ \\
\hline Spinal arrangement on endopodite of 1 st maxilliped & $*$ & $3-2-1-2-5$ & $3-2-1-2-5$ \\
\hline Spinal arrangement on protopodite of 1 st maxilliped & * & $2-2-3-3$ & $2-2-3-3$ \\
\hline Spinal arrangement on endopodite of 2 nd maxilliped & * & $1-1-5$ & $1-1-5$ \\
\hline Spinal arrangement on protopodite of 2 nd maxilliped & $*$ & $1-1-1-1$ & $1-1-1-1$ \\
\hline
\end{tabular}

\section{Discussion}

In order to identify brachyuran zoeae, AIKAWA ${ }^{1 /}$ proposed the following four characters: 1) spine on the carapace, 2) character of the second antenna, 3) character of the telson including its armature, and 4) grouping of chromatophores. According to his criteria, the characters of $C$. japonicus zoea may be summarized as follows: all the spines present on carapace, second antenna B-type, telson A-type, chromatophores of vermil, lion or crimson in color present on second to fifth abdominal segments, protopodite of the first maxilliped, on the carapace and mandible. These characters almost agree with those for $C$. opilio except color and the following characters. According to HAY$\mathrm{NES}^{9}$, the first zoea of $C$. bairdi and $C$. opilio from the Bering Sea has three aesthetes and two setae on the antennule, whereas in $C$. opilio ${ }^{10}$ and $C$. japonicus the antennule has two aesthetes and one seta. Also according to HAYNES ${ }^{9}$, in the first zoea, the length of the posterior lateral spines on 3rd abdominal segment extends beyond the posterior margin of the adjacent segment about one-third the length of the spine in $C$. bairdi, but in $C$. opilio they barely reaches the posterior margin of the adjacent segment. In point of this, in $C$. japonicus, the posterior lateral spine is more than 1.3 times the length of 4th abdominal segment, but is shorter than (rarely equal to) those in C. opilio. ${ }^{10)}$ 


\section{Acknowledgements}

The present author wishes to express his deepest appreciation to Dr. Hiroshi KURATA, Nanseikai Regional Fisheries Research Laboratory, and Mr. Katsuchiyo ITo, Japan Sea Regional Fisheries Research Laboratory, Dr. Emer. Prof. Kikuya MasHIKo, Faculty of Science, University of Kanazawa, for their valuable suggestions through his work and helpful criticism on the manuscript. Thanks are also tendered to Dr. Noboru Hoshino, Aquaculture Department, SEAFDEC, and Mr. Tadanobu Ero, Marine Culture Station of Ishikawa Prefecture, for giving him the opportunity to continue his experiment, and Mr. Noboru Nakura, Fisheries Experimental Station of Toyama Prefecture, for sending the ovigerous crabs to him; Messrs. Tetsuo Mrnagawa and Fusao Nagata, Marine Culture Station of Ishikawa Prefecture, and Mrs. Elsie C. Pedrigal, Aquaculture Department, SEAFDEC, for their valuable assistance during the course of this experiment.

\section{References}

1) H. Alkawa: Rec. Oceanog. Works Japan, 2, 17-55 (1929).

2) H. Arkawa: Zool. Mag., 47, 217-227 (1935).

3) H. Alkawa: Rec. Oceanog. Works Japan, 9, 87-162 (1937).

4) T. Kon: This Bull., 33, 726-730 (1967).

5) K. Ito: Bull. Jap. Sea Reg. Fish. Res. Lab., (20): 91-93 (1968).

6) H. Kurata: Bull. Hokkaido Reg. Fish. Res. Lab., (27): 25-31 (1968).

7) H. KuRata: Bull. Tokai Reg. Fish. Res. Lab., (57): 117-119 (1969).

8) Y. Kuwatani, T. Wakut and T. NAKantsh: Bull. Hokkaido Reg. Fish. Res. Lab., (37): 32-40 (1971).

9) E. HAYnes: Fish. Bull., 71(3): 769-775 (1973).

10) H. MoтoH: This Bull., 39, 1223-1230 (1973).

11) H. Мотон: Special publ. Pref. Mar. Cult. Sta. Ishikawa, 7-11 (1970).

12) H. FukATAKI: Bull. Jap. Sea Reg. Fish. Res. Lab., (21): 35-54 (1969).

13) K. Ito and K. IKeHARA: ibid., (23): 83-100 (1971). 